\title{
Normal "Abnormalities" in Palms ${ }^{1}$
}

\section{T. K. Broschat and M.L. Elliott ${ }^{2}$}

Consultants and extension agents are frequently approached by palm owners with concerns about the abnormal appearance of their palms. Most of these abnormalities turn out to be symptoms of a disease, insect, nutritional or other physiological disorder. However, some of these "abnormalities" turn out to be perfectly normal for that particular palm species. This document was developed to describe and illustrate some of these common "abnormalities" that cause concern among palm owners.

\section{Root "Problems"}

All palm roots are adventitious in origin. That is, they arise directly from stem tissue rather from other larger roots. Palm roots emerge from the base of the trunk in an area called the root initiation zone. This area starts in the center of the bottom of the stem in palm seedlings. As the palm develops, it expands outward and upward, eventually working its way upward along the base of the trunk. Where these root initials are in contact with the soil or other moist environment, they will continue their development, growing outward and downward into the soil as typical functioning roots. Those root initials that arise from above-ground portions of the root initiation zone typically are exposed to a drier environment and their growth and development are arrested. These root initials can resume growth at any time if their environment becomes moist enough to support their growth. Although the visible aerial portion of the root initiation zone on most palms extends up the trunk no more than six to 12 inches (Fig. 1), on some date palms (Phoenix spp.) the root initiation zone can extend several feet up the trunk (Fig. 2).

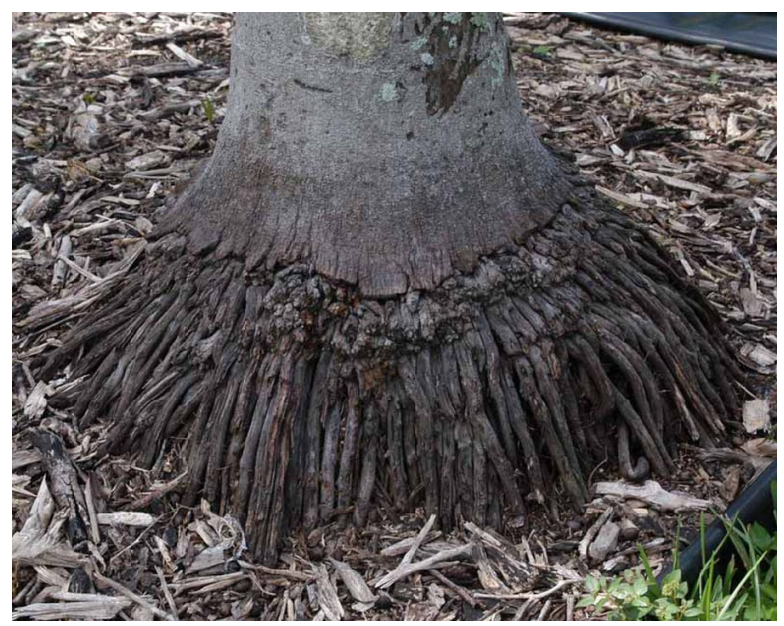

Figure 1. Typical aerial portion of the root initiation zone on a mature palm.

1. This document is ENH1077, one of a series of the Environmental Horticulture Department, Florida Cooperative Extension Service, Institute of Food and Agricultural Sciences, University of Florida. Original publication date October 2007. Visit the EDIS Web Site at http://edis.ifas.ufl.edu.

2. Timothy K Broschat, professor, Environmental Horticulture Department, Ft. Lauderdale Research and Education Center, and M. L. Elliott, professor, Plant Pathology Department, Fort Lauderdale Research and Education Center--Ft. Lauderdale, FL; Florida Cooperative Extension Service, Institute of Food and Agricultural Sciences, University of Florida, Gainesville, FL.

The Institute of Food and Agricultural Sciences (IFAS) is an Equal Opportunity Institution authorized to provide research, educational information and other services only to individuals and institutions that function with non-discrimination with respect to race, creed, color, religion, age, disability, sex, sexual orientation, marital status, national origin, political opinions or affiliations. U.S. Department of Agriculture, Cooperative Extension Service, University of Florida, IFAS, Florida A. \& M. University Cooperative Extension Program, and Boards of County Commissioners Cooperating. Larry Arrington, Dean 


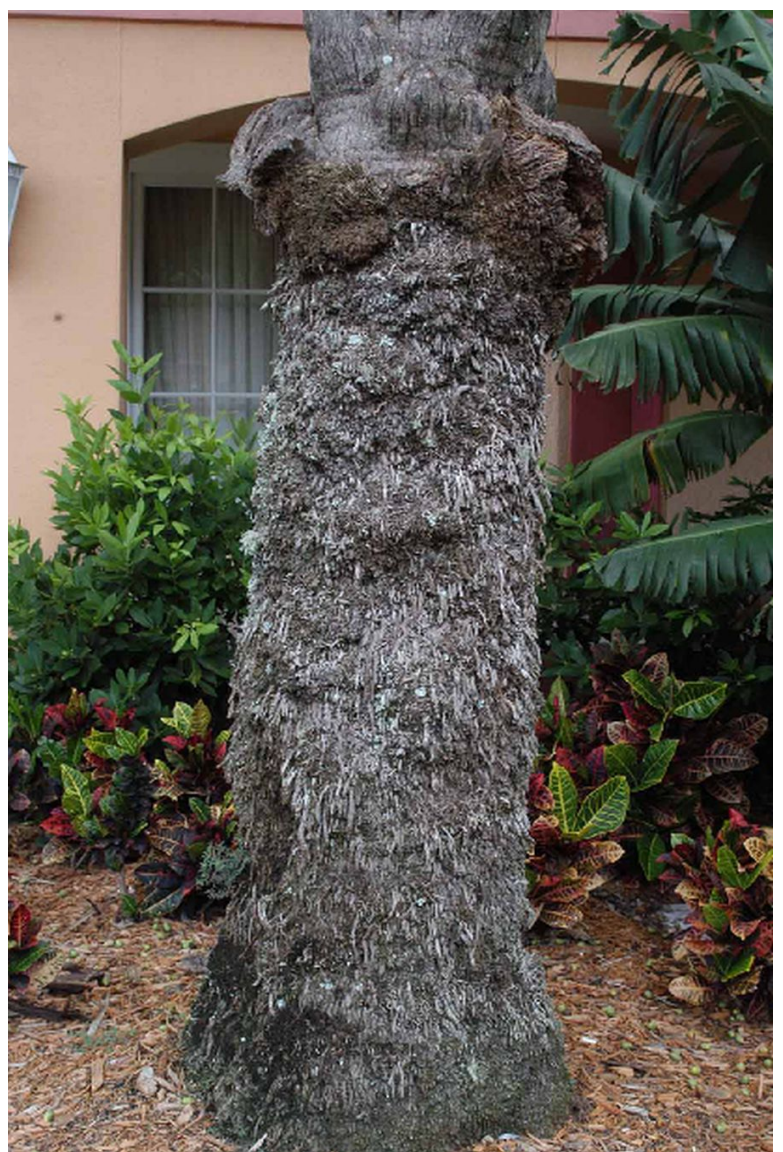

Figure 2. Root initiation zone extending several feet up the trunk in Phoenix dactyifera.

\section{Splitting and Spreading of the "Bark" at the Base of the Trunk}

As the root initiation zone on older palms expands up above the soil line, these new root initials, which arise from tissue under the "bark" (cortex) of the palm trunk, eventually force the "bark" outward in a flared fashion (Fig. 3). This is a normal part of development as a palm matures, but the degree to which this "bark" flares out varies among palms.

\section{Stilt Roots}

A few genera of palms, commonly referred to as stilt palms, normally produce a few large-diameter roots from the above-ground portion of the root initiation zone. Unlike most aerial root initials, those in stilt palms can continue their development, even in the absence of a moist soil environment. These large roots grow downward into the soil, supporting and anchoring the palm stem above ground. These roots are referred to as stilt roots (Fig. 4). Stilt roots are

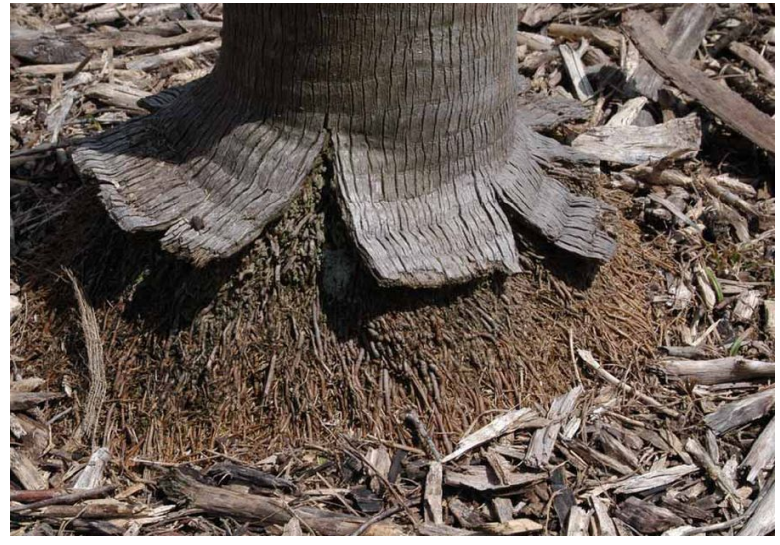

Figure 3. Flared "bark" caused by development of root initials underneath.

largely confined to palms within the genera Iriartea, Socratea, and Verschafeltia.

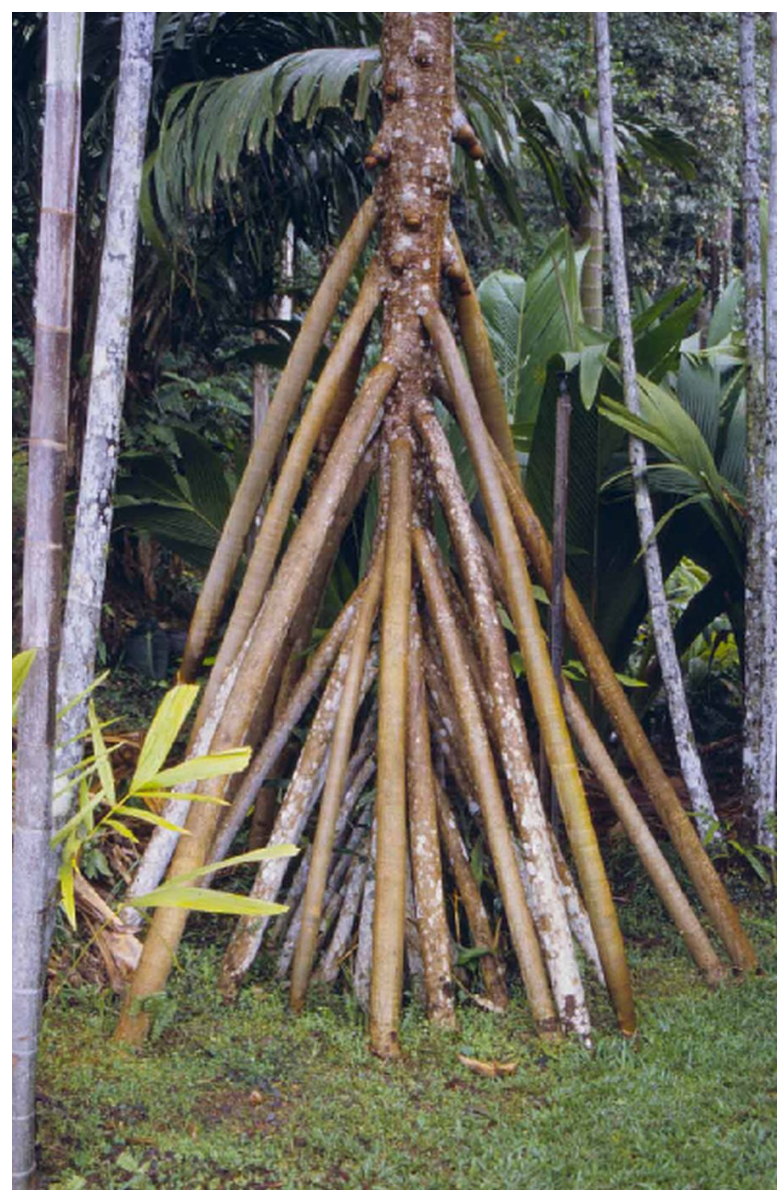

Figure 4. Stilt roots on Iriartea sp. 


\section{Trunk "Problems"}

\section{Shedding of Leaf Bases}

When Mexican fan palms (Washingtonia robusta) are relatively young (less than 10 years old), old dead leaves remain firmly attached to the trunk, forming a skirt of dead leaves (Fig. 5). If these leaves are cut off at the petioles, the leaf bases will also remain tightly attached to the trunk. After these palms reach a certain age or stage of maturity (about 10-15 years in Florida), these old leaves or leaf bases will suddenly begin to fall off in large numbers, leaving gaps in the skirt of leaves or leaf bases (Fig. 6). Within a year or so, virtually all of the old dead leaves and leaf bases will have been shed, leaving a clean trunk with a canopy of living leaves at the top. Once this stage of maturity is reached, the palm becomes largely self-cleaning, that is, old leaves will fall off naturally as they die rather than having to be cut off manually.

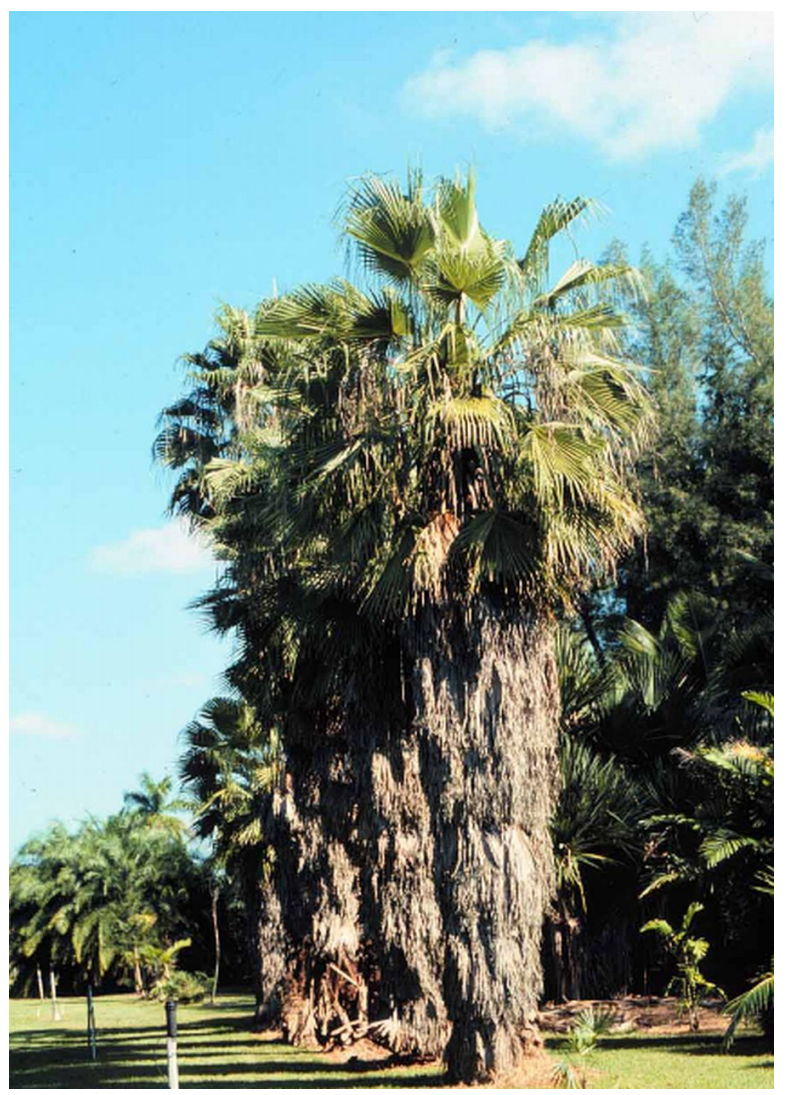

Figure 5. Young Washingtonia robusta showing skirt of retained dead leaves.

In sabal palms (Sabal palmetto), people often ask why some trunks are smooth and others have an

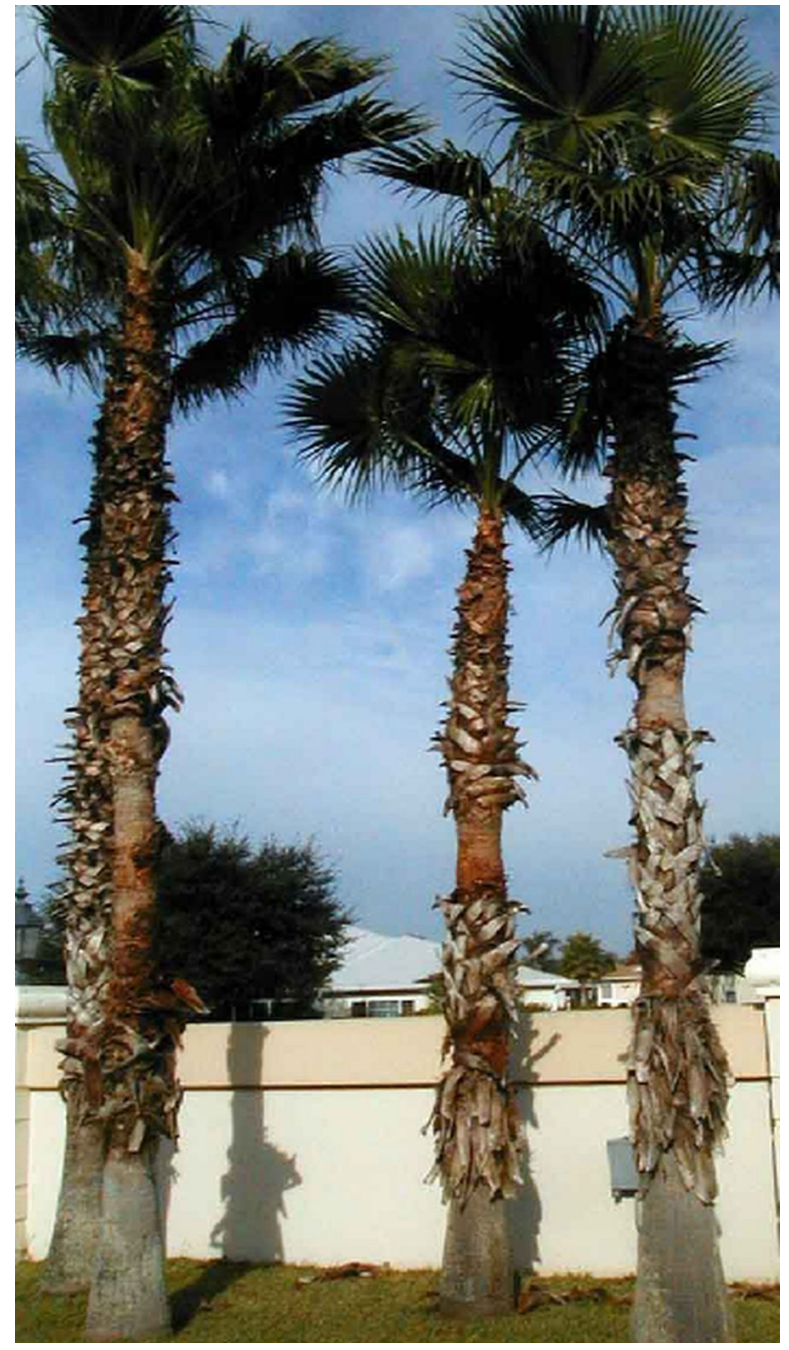

Figure 6. Older (10-15 years old) Washingtonia robusta dropping old leaf bases.

attractive pattern of old leaf bases ("boots") firmly attached (Fig. 7). There are two explanations for this. The first is that the natural retention versus shedding of old leaf bases by individual palms is probably genetically determined. Since all sabal palms are seed propagated and thus are genetically different, some will retain their old leaf bases for 50 years or longer, while others shed their old bases after 5-10 years. The second explanation is that those leaf bases that may remain on a sabal palm are manually cut off by the installer prior to transplanting into the landscape, making the trunk appear smooth.

\section{Trunk Erosion}

It is not uncommon to find old specimens of palms of various species with eroded trunks (Fig. 8). The cause of this erosion has never been determined, but no disease pathogens have been isolated from 


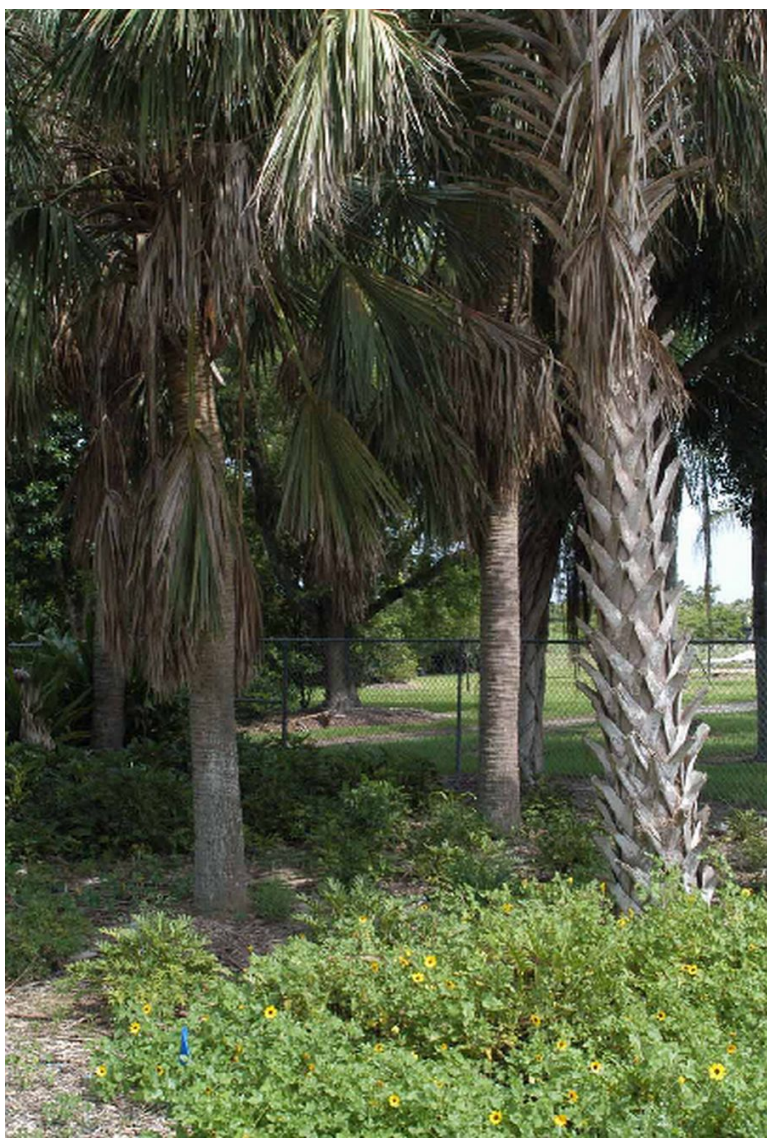

Figure 7. Smooth and "booted" trunks on Sabal palmetto of similar ages.

tissue that is in the process of falling off. This erosion of the softer cortical tissue from the outside of the trunk is considered normal for older specimens of some species. In most cases the central cylinder, which contains fibers and vascular tissue, remains intact due to the high concentration of sclerified fibers. Loss of sections of palm trunk cortex does not seem to negatively impact palm structural strength or the uptake of water and nutrients, although it certainly can be unsightly.

\section{Leaf "Problems"}

\section{Scurf on Young Leaves}

Many people, when they first look closely at a young leaf of a pygmy date palm (Phoenix roebelenii), believe that they are seeing a severe infestation of a scale insect (Fig. 9). These white, elongated, slightly-raised "objects" are all longitudinally oriented along the axis of the rachis and leaflets of relatively young leaves in this species. As the leaves age, this scurf eventually falls off.

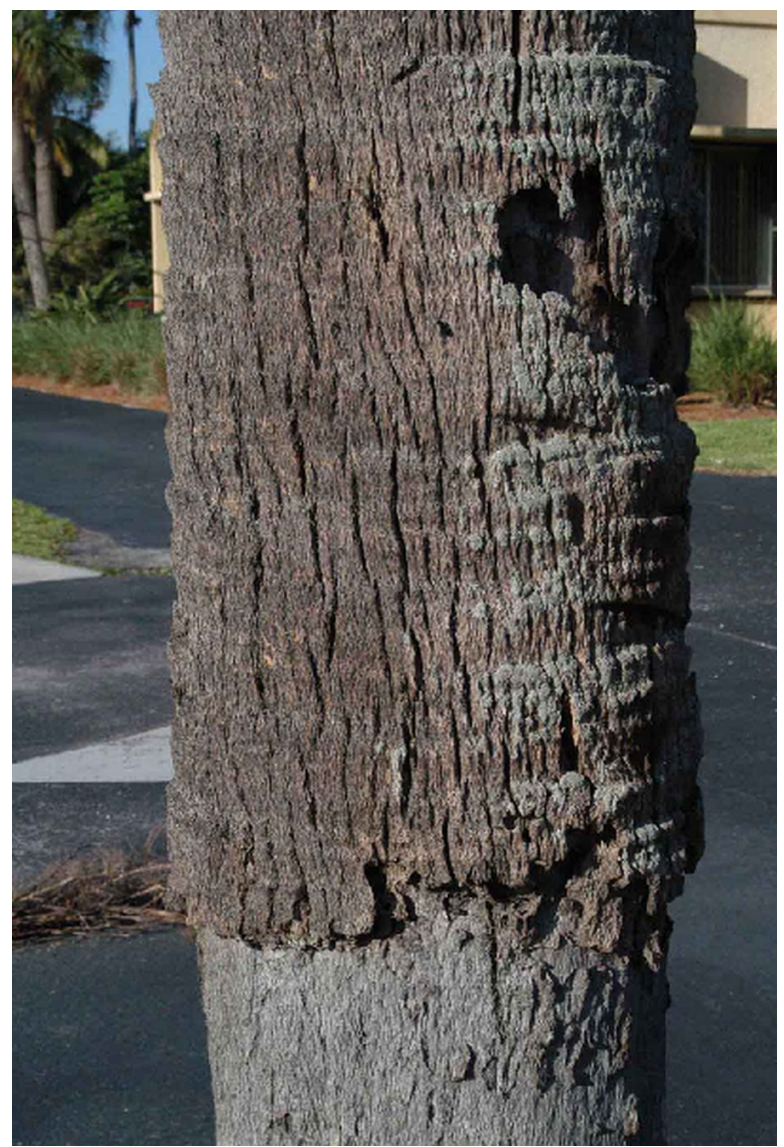

Figure 8. Eroded trunk cortex of old Sabal palmetto.

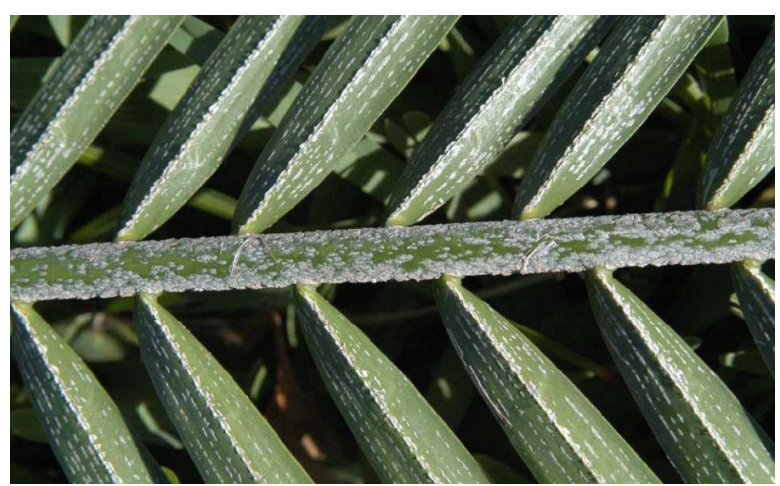

Figure 9. White scurf on young leaf of Phoenix roebelenii.

In some palms ( e.g., Wodyetia bifurcata, Veitchia spp.) black-colored scurf appears at the bases of the petioles (Fig. 10). This black scurf is very similar in appearance to the sooty mold often associated with palm aphids, scales, or mealybugs. In other palms, new spear leaves and young petioles are covered with a thick pinkish to brown fuzzy scurf that is easily rubbed off. The light salmon-colored scurf on new growth of Latania palms (Fig. 11) is useful in distinguishing this species from the similar Bismarck palm (Bismarckia nobilis), which has very little scurf. 


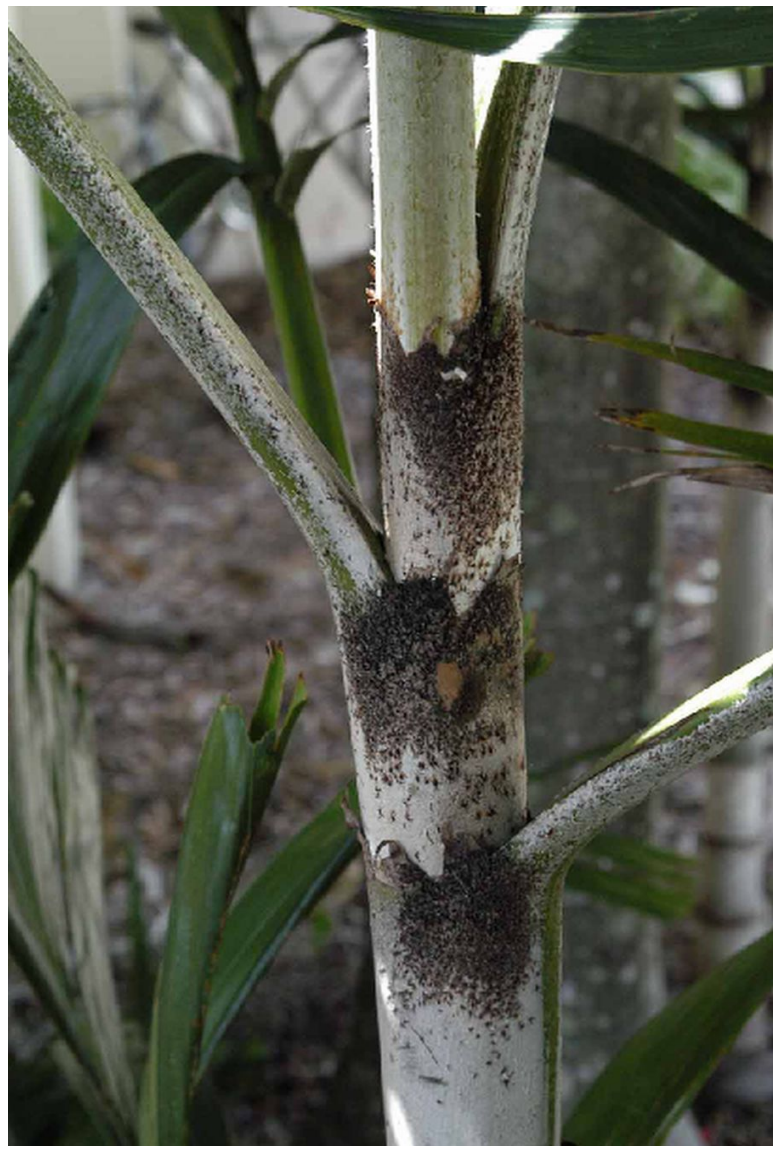

Figure 10. Black scurf on crownshaft of Vetchia sp.

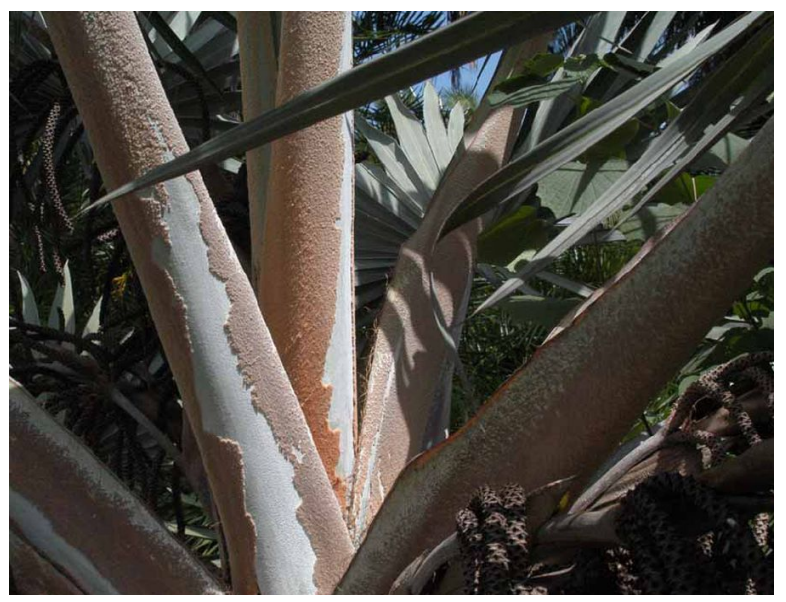

Figure 11. Pinkish scurf on spear and petioles of Latania lontaroides.

\section{Reins}

On some feather palm species, you will occasionally observe long, narrow strips of green tissue hanging down like long shoe strings from the leaves (Fig.12). These appendages are called reins, and they were originally connective tissue attached along the edges of the leaflets when they were folded in the unopened spear leaf. As the spear opens, this strip of extraneous tissue usually falls off, but occasionally remains attached to one of the leaflets on young leaves.

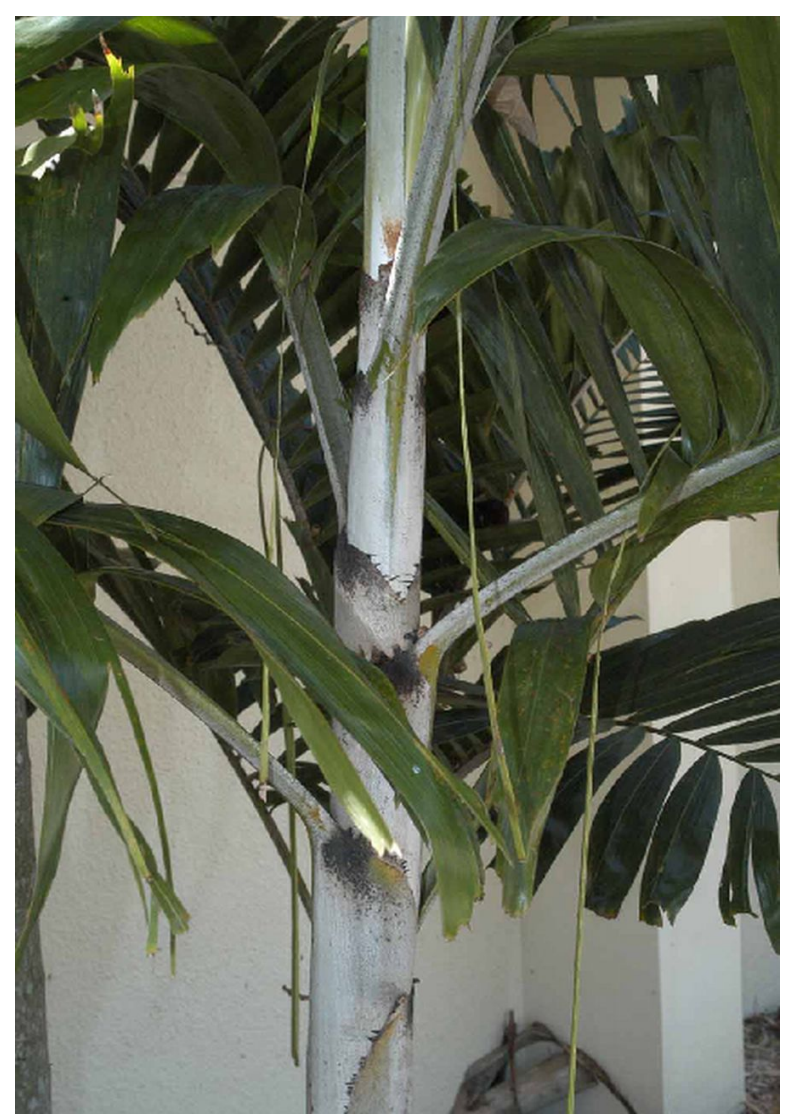

Figure 12. Reins on young leaves of Veitchia sp.

\section{Clear Areas on Leaves of Sabal Palms}

One of the best methods for diagnosing potassium deficiency is to hold an older leaf up to the light and observe the translucent yellow-orange spotting that is characteristic of this disorder. However, sabal palm leaves typically show a region of translucent yellow-green tissue at the bases of the leaflets along the costa (rib) of the leaf (Fig. 13). This is normal for this species and it appears on leaves of all ages.

\section{Crumpled New Leaves on Clustering Palms}

Small, crumpled new leaves in most palm species are a symptom of boron deficiency. However, in clustering palm species such as areca palm (Dypsis lutescens), when a new side shoot is emerging through the side of the crownshaft, the first leaf is invariably crumpled in appearance (Fig. 14). The next leaf produced on the side shoot is usually 


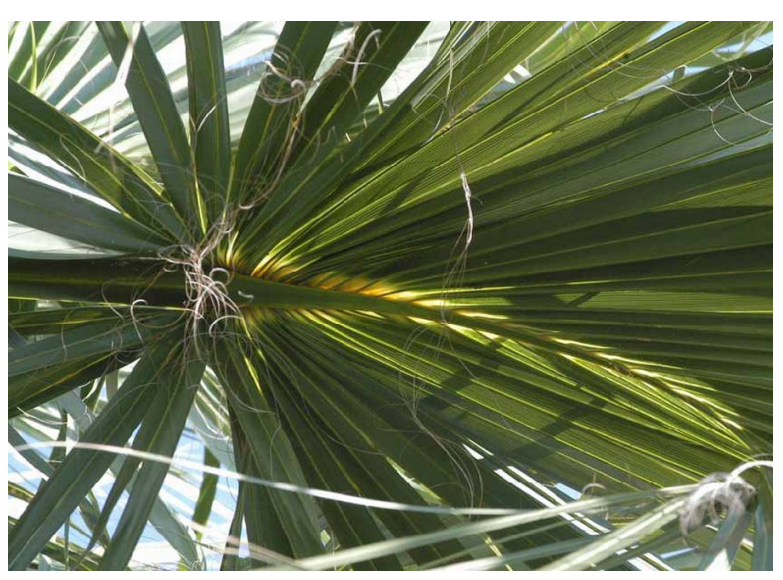

Figure 13. Translucent area on leaf of Sabal palmetto.

normal in appearance, but may occasionally show some crumpling. Subsequent leaves will appear normal.

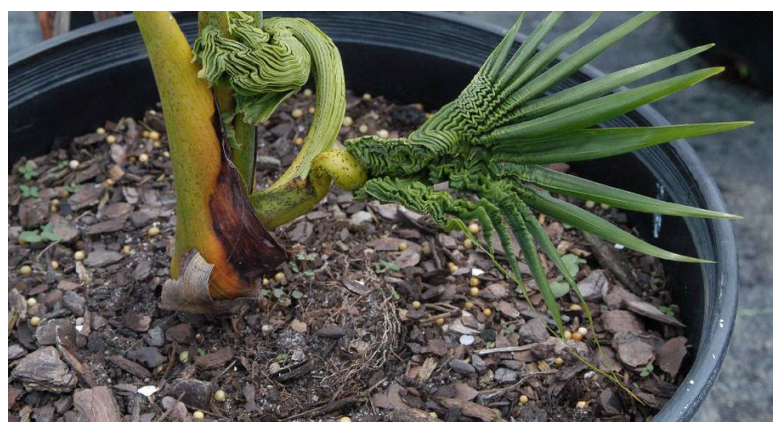

Figure 14. Crumpled new leaf emerging as a side shoot on Dypsis lutescens.

\section{Yellow to Orange Coloration of Petioles, Rachi, and Inflorescences in Coconut Palms}

Although golden yellow petioles and crownshafts in areca palms are an indication of nitrogen deficiency, this same pattern on some cultivars of coconut palms is genetically determined and thus is perfectly normal for the variety (Fig. 15). For example, in coconut cultivars such as 'Golden' (='Red') 'Malayan Dwarf', 'Yellow Malayan Dwarf', and 'Red Spicata', properly fertilized specimens will have light yellow to intense orange-red colored petioles, rachi, inflorescences, and immature fruits. Leaflets on these palms should have dark green lamina, but the midvein can be yellow. If the leaflets are not green, that is an indication of a nutrient deficiency.

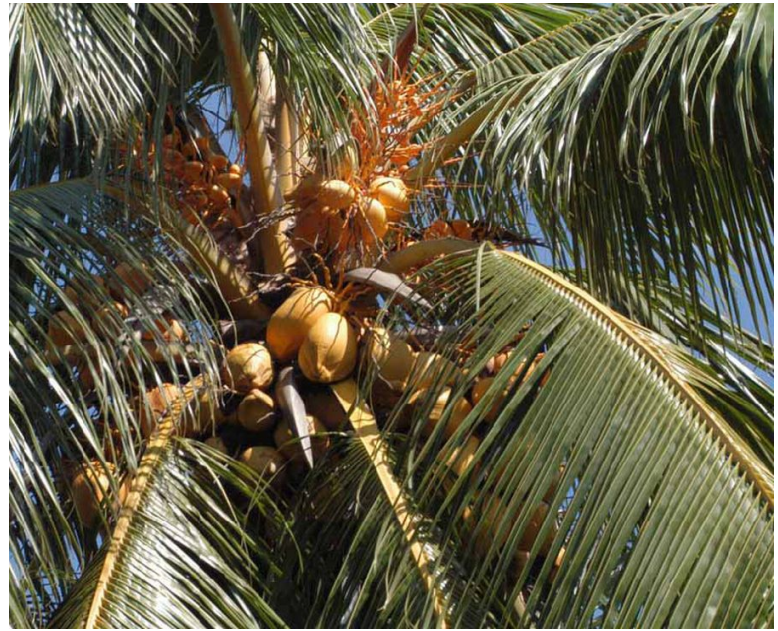

Figure 15. Normal golden yellow colored petioles, rachi, and inflorescences in 'Golden Malayan Dwarf' coconut palm.

\section{Palms Dying after Flowering and Fruiting (Hapaxanthy)}

Certain species of palms (Caryota spp., Corypha spp., Arenga spp., some Metroxylon spp., etc.) flower and fruit only once when the palm is fully mature. After fruiting, the palm dies-often much to the surprise of the palm owner. Hapaxanthic palms may produce a single massive terminal inflorescence (Fig. 16), or they may flower at each node along the trunk (Fig.

17). Contrary to popular belief, clustering fishtail palm (Caryota mitis) stems all die within a period of a year or two after flowering. Any new growths arising from the clump are seedlings that have germinated, not vegetative shoots from the original clump. 


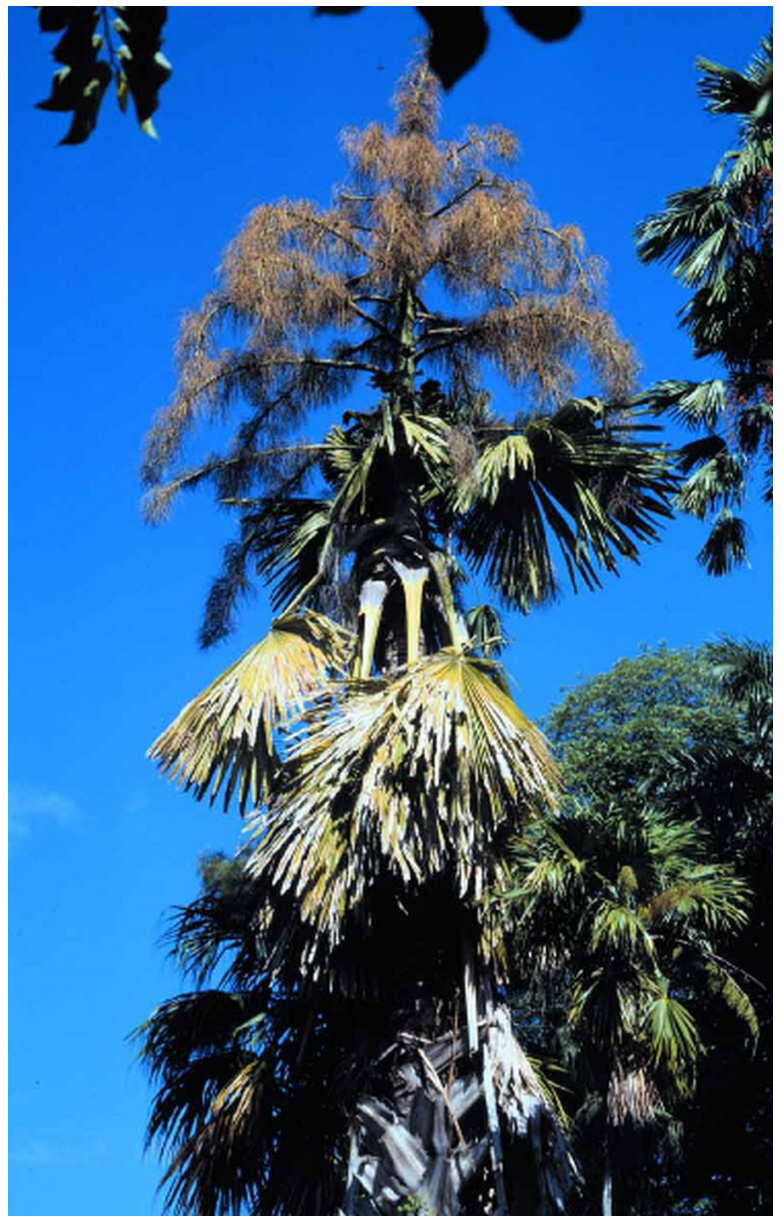

Figure 16. Terminal flowering in mature Corypha sp. It will die after fruiting.

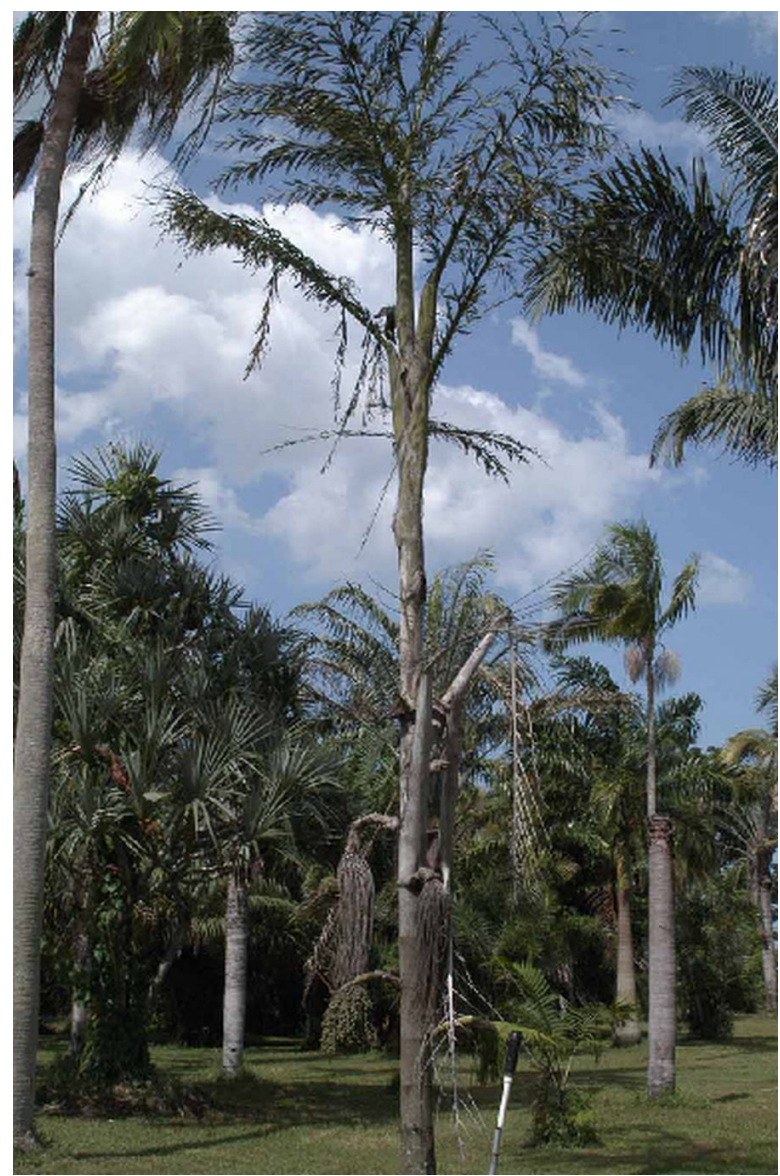

Figure 17. Dead Caryota urens that has just completed its fruiting. 